\title{
BOKRECENSION
}

Jesper Haglund är universitetslektor i fysikens didaktik vid Karlstads universitet. Han disputerade 2012 i natur-

vetenskapernas didaktik vid Linköpings universitet och är docent i fysik med inriktning mot fysikens didaktik vid

Uppsala universitet. Haglund undervisar på lärarutbildningen, främst i fysikdidaktik och med handledning av

examensarbeten, och hans forskning fokuserar på elevers och studenters lärande i värmelära och termodynamik.

JESPER HAGLUND

Institution: Institutionen för ingenjörsvetenskap och fysik, Karlstads universitet, Sverige

jesper.haglund@kau.se

\section{Bokrecension av Fysikkdidaktikk, 2. utgave, av Angell et al.}

I juli 2019 publicerades andra utgåvan av Fysikkdidaktikk vid Cappelen Damm (Angell et al., 2019). Boken är skriven på norska (bokmål) och är ett samarbete mellan sex fysikdidaktiker från Oslo, Bergen, Trondheim och Kristiansand som huvudförfattare, och därutöver bidrar ytterligare didaktiker som medförfattare till några av de ingående kapitlen. Denna andra utgåva är en omarbetning av den första utgåvan av samma författare från 2011 (Angell et al., 2011). Som det träffande är beskrivet i baksidestexten ger boken en "helhetlig framstilling av fysikk som undervisningsfag i norsk utdanningssystem”. Boken är huvudsakligen skriven för att kunna användas i kurser i fysikdidaktik på lärarutbildningar, och har fokus på videregående skole (gymnasium). Den utgår från resultat och slutsatser från fysikdidaktisk forskning för att stimulera till reflektion kring undervisningspraktiken.

Boken är indelad i sex delar, bestående av totalt 29 kapitel, där delarna avslutas med diskussionsfrågor. I del 1, Hva er fysikk?, ges en beskrivning av fysikens karaktär som ämnesområde och akademisk disciplin, samt dess historiska utveckling. Bland annat exemplifieras centrala teman kring arbetssätt och synsätt i fysiken, såsom strävan efter falsifierbarhet och observationers beroende av bakomliggande teorier, på ett konkret sätt med hjälp av en redogörelse för Comptons utforskande av Compton-effekten som historiskt fall.

Del 2, Fysikkfaget i norsk utdanning, redogör för hur fysikutbildningen i Norge har utvecklats i ett historiskt perspektiv, samt ger en beskrivning av vad som kännetecknar elever, lärare och skolundervisningen i fysik i Norge idag. Dessa delar bygger till stor del på resultat från norsk forskning och utvärderingar av skolan i större undersökningar. Den traditionella fysikundervisningen, där lärares genomgång och elevers enskilda räkning dominerar, problematiseras utifrån lärande och motivation, inte minst för flickor.

I del 3, Å lære fysikk, introduceras internationell forskning om elevers och studenters förståelse för centrala begrepp inom fysiken, inte minst med fokus på elevers alternativa föreställningar. Här ges även en kort redogörelse för olika lärteorier, som konstruktivism och ett sociokulturellt perspektiv på lärande. 
Del 4, Å undervise fysikk som teoretisk og ekperimentelt fag, är ett omfattande avsnitt av boken, där flera olika aspekter på fysikundervisning behandlas. Övergripande lyfts variation i undervisningsformer fram som en framgångsfaktor. I ett kapitel om den roll experiment har i fysikundervisningen betonas att man som lärare behöver tänka igenom syfte och lärandemål för ett visst experiment, då detta kan variera mycket från fall till fall. Nära kopplat till detta beskrivs utforskande arbetssätt som ett sätt att öppna upp fler frihetsgrader än vad som erbjuds med "kokbokslaborationer", där forskningen dock pekar på vikten av stöttning från lärare. Ett kapitel beskriver modellering som en central aktivitet i att koppla mätningar och fenomen till teorier som beskriver dem, med modellering av luftmotståndet då muffinsformar faller som ett åskådliggörande och inspirerande exempel. Fysikens språk är i fokus i kapitel som uppmuntrar till att ge elever tillfälle att föra dialog om fysiken och erfarenhet av skrivande i olika genrer. Delen avslutas med en diskussion av hur olika typer av digitala verktyg kan användas i undervisningen, som simuleringsverktyg och stöd för administration av flervalsfrågor.

Medan del 4 kan sägas ha ett processperspektiv på undervisningen fokuserar del 5 , Fysikkfagets innhold, på fysikens olika delområden, med redogörelser för forskning om elevers begreppsförståelse och konkreta förslag på hur man som lärare kan lägga upp undervisningen i respektive område. Inom mekaniken betonas den Newtonska fysikens icke-intuitiva karaktär, och här beskrivs till exempel möjligheter att låta elever använda sina kroppar genom att putta varandra då de sitter på kontorsstolar för att känna de krafter som verkar eller använda rörelsesensorer för att skapa t.ex. läge-tid-grafer i realtid. I relation till undervisning om elektiska kretsar argumenterar författarna för en användning av flera olika analogier som var och en för sig har olika brister, men på ett kompletterande sätt belyser fenomenet. De lyfter fram hur historiska och filosofiska perspektiv lämpar sig särskilt för undervisning i kvantfysik. I tillägg till Compton-effekten som historiskt fall i del 1 presenteras här motståndet Einstein möttes av bland fysiker i sin tolkning av ljuskvanta i relation till fotoelektriska effekten, som kontrast till en alltför förenklad beskrivning av den historiska utvecklingen som elever ofta ges. De pekar vidare på hur många elever visar stort intresse för astrofysik, med dess kosmologiska frågor och uppmärksamhet för nya rön i populära media, och föreslår hur speciell och allmän relativitetsteori kan introduceras på gymnasiet, liksom för kvantfysiken inte minst kvalitativt genom diskussionsfrågor i mindre grupper kring hur teorin skiljer sig från antaganden i klassisk fysik. I ett avslutande kapitel diskuteras hur man kan hjälpa elever att förstå fysikens karaktär, i en situation då många av dem är naiva realister med en förenklad syn på objektiv tolkning av data. Dramatisering kan här vara en ansats, där eleverna antar olika roller i relation till frågor med samhällsrelevans, som energiförsörjning.

Avslutningsvis introduceras i del 6, Tester och vurdering i fysikkfaget, begreppen summativ och formativ bedömning. Här anförs på ett tankeväckande sätt även flera goda argument för att användning av flervalsfrågor vid skriftliga prov skulle kunna få en mer framträdande roll i norsk skola än vad de traditionellt har haft, och formell testteori introduceras.

I jämförelse med den första utgåvan följer boken samma struktur, men de flesta kapitel har omarbetats en hel del. Del 1, kring fysiken i sig, har kortats något och specifika frågor om aktuella norska styrdokument har tonats ner, vilket har gett mer plats till bokens huvudfokus - undervisning och lärande av fysik - på ett bra sätt. Nya undervisningsmaterial och forskningsresultat, som inte minst flera av författarna själva har bidragit till under åren sedan 2011 genom projekt som IRIS (Henriksen, Dillon, \& Ryder, 2015) och ReleKvant (Bungum, Henriksen, Angell, Tellefsen, \& Bøe, 2015), har bidragit till utförligare redogörelser av elevers motivation och studieval i Del 2, samt undervisning om kvantfysik och - i ett helt nytt kapitel - om relativitetsteori i Del 5. Jag upplever dock utökade avsnitt om statistisk analys av mätdata med regression i anknytning till användning av experiment och fördjupningen om testteori, utifrån Rasch-modellering, som ett av avsteg från detta undervisningsfokus.

Övergripande lyckas författarna bra med sin ambition att ge en helhet över fysikdidaktiken som område. Boken balanserar många av fysikdidaktikens grundläggande frågeställningar på ett på ett imponerande sätt. Den är tydligt förankrad i den internationella fysikdidaktiska forskningen i stort, men 
gör nedslag i forskning där författarna själva har bidragit. Den ger en fördjupande teoretisk förståelse, vilken även kopplas till konkreta rekommendationer och exempel i fysikundervisningen. Att boken är inriktad på de särskilda förutsättningarna för fysikundervisningen på gymnasienivån upplever jag som ett unikt bidrag åtminstone i Skandinavien, men jag har heller inte sett en text med motsvarande omfattning på engelska, då annan liknande litteratur som regel antingen fokuserar på grundskolan eller högskolenivån.

Vid Karlstads universitet har vi använt första utgåvan av Fysikkdidaktikk som kurslitteratur i fysikdidaktik på lärarutbildningen av blivande lärare i fysik med inriktning mot gymnasiet i några år. Vi uppskattar särskilt att boken ofta presenterar många perspektiv på olika frågor, som till exempel både fördelar och utmaningar med undersökande arbetssätt eller att låta elever lösa uppgifter enskilt i klassrummet. Tillsammans med diskussionsfrågorna stimulerar detta till reflektion och diskussion kring undervisning och lärande i fysik, vilket är centralt för att våra studenter ska kunna utveckla ett medvetet förhållningssätt till undervisningen och sin roll som fysiklärare. Vi upplever att det mesta av bokens innehåll är relevant även i relation till den svenska gymnasieundervisningen i fysik. Vissa avsnitt är specifika för det norska skolsystemet, men beskrivningen av vad som försiggår i det norska klassrummet känns igen även hos oss, och avsnitt om elevers förståelse och olika undervisningsupplägg kan användas rakt av i våra kurser. Det är visserligen en utmaning för flera av våra studenter att läsa en text på norska. Många av våra ämneslärarstudenter läser ämneskurser i fysik parallellt med fysikdidaktiken, och det kan upplevas som att språket blir ett ytterligare hinder i att förstå ett stoff som är ganska krävande i sig, t.ex. kring lärteorier, filosofiska aspekter på fysiken eller fenomen i modern fysik som de ännu inte har läst. Vi upplever dock att fördelarna med att ha en sammanhållen text med fokus på fysikundervisningen på gymnasiet i en skandinavisk kontext överväger. Något annat som kan avskräcka från att använda boken som kurslitteratur är det förhållandevis höga priset, vilket dock ska vägas mot alternativet att använda flera andra böcker för att behandla motsvarande stoff.

\section{Tack}

Jag vill tacka mina kollegor vid Karlstads universitet, Morgan Leander för stimulerande diskussioner kring användning av boken Fysikkdidaktikk på lärarutbildningen och Jan Andersson för konstruktiva kommentarer på texten.

\section{REFERENSER}

Angell, C., Bungum, B., Henriksen, E. K., Kolstø, S. D., Persson, J., \& Renstrøm, R. (2011). Fysikkdidaktikk (1. utgave). Kristiansand: Høyskoleforlaget.

Angell, C., Bungum, B., Henriksen, E. K., Kolstø, S. D., Persson, J., \& Renstrøm, R. (2019). Fysikkdidaktikk (2. utgave). Oslo: Cappelen Damm.

Bungum, B., Henriksen, E. K., Angell, C., Tellefsen, C. W., \& Bøe, M. V. (2015). ReleQuant - Improving teaching and learning in quantum physics through educational design research. Nordic Studies in Science Education, 11(2), 153-168. doi:10.5617/nordina.2043

Henriksen, E. K., Dillon, J., \& Ryder, J. (2015). Understanding student participation and choice in science and technology education. Dordrecht, the Netherlands: Springer. doi:10.1007/978-94oo7-7793-4 